OPEN ACCESS

Vol. 7, No. 1, April, 2019

Page. $1-43$

DOI: https://doi.org/10.21107/jaffa.v7i1.6145
JOURNAL OF AUDITING, FINANCE, AND FORENSIC ACCOUNTING (JAFFA)

E-ISSN: 2461-0607 ISSN: 2339-2886

https://journal.trunojoyo.ac.id/jaffa/index

\title{
INVENTORY ACCOUNTING METHODS: FACTORS AFFECTING BASIS OF THE CHOICE
}

Rendy Aprianto Maha Putra, Anita Carolina

Accounting Department, Faculty of Economics and Business, University of Trunojoyo Madura

Article Info:

Received: 19 September 2019

in revised form: 03 Oktober 2019

Accepted: 21 November 2019

Available Online: 19 December 2019

Keywords:

company size

inventory variability

cost of goods sold variability, gross

profit margin, leverage

current ratio,

managerial ownership, choice of

inventory accounting methods

Corresponding Author:

Email: rendypriantomp@gmail.com

\begin{abstract}
This research aims to analyze the effects of company size, inventory variability, cost of goods sold variability, gross profit margin, leverage, current ratio, and managerial ownership in selecting the inventory accounting methods. The population of this research was manufacturing companies listed in the Indonesia Stock Exchange in 2015-2018. In addition, this research used a purposive sampling method to determine the sample. The research results indicate that company size and inventory variability affect the choice of inventory accounting methods, while variability of cost of goods sold, gross profit margin, leverage, current ratio, and managerial ownership do not affect the choice of inventory accounting methods.
\end{abstract}

\begin{abstract}
Abstrak; Penelitian ini bertujuan untuk menganalisis pengaruh ukuran perusahaan, variabilitas persediaan, variabilitas harga pokok penjualan, margin laba kotor, leverage, rasio lancar, dan kepemilikan manajerial dalam memilih metode akuntansi persediaan. Populasi penelitian ini adalah perusahaan manufaktur yang terdaftar di Bursa Efek Indonesia pada tahun 20152018. Selain itu, penelitian ini menggunakan metode purposive sampling untuk menentukan sampel. Hasil penelitian menunjukkan bahwa ukuran perusahaan dan variabilitas persediaan mempengaruhi pilihan metode akuntansi persediaan, sedangkan variabilitas harga pokok penjualan, margin laba kotor, leverage, rasio lancar, dan kepemilikan manajerial tidak mempengaruhi pilihan metode akuntansi persediaan.
\end{abstract}




\section{INTRODUCTION}

Inventory is the largest current asset of a manufacturing company. The choice of inventory accounting methods has a direct impact on profits, taxes, and ending inventory in a company and has a very strong correlation with profits, taxes, and ending inventory (Simeon and John, 2018). In 2008, Indonesia Financial Accounting Standards (PSAK) 14 was revised with only 2 types of inventory accounting methods recognized and allowed, that is FIFO and average methods. The revision is directly proportional to the tax regulations in Indonesia contained in Article 10 Paragraph 6 of Law Number 10 of 1994 on Income Tax which only recognizes FIFO and average methods.

The main operation of manufacturing companies is processing raw materials into finished goods to be sold. Consequently, they have various types of inventory and require them to choose the inventory accounting method properly because the selection of inventory accounting methods will have a significant impact on their financial statements, especially the statement of financial position and income statement. Then, the issuance of regulation on inventory in PSAK 14 (revised 2008) which is applicable since 2009 has given the most significant impact because manufacturing companies have more complex production processes and most of the data in manufacturing companies is the information about inventory.

\section{LITERATURE REVIEW AND HYPOTHESES DEVELOPMENT}

\section{Positive Accounting Theory}

According to Scott $(2000)$, managers tend to take actions which, according to positive accounting theory, are called opportunistic behavior. Watts and Zimmerman (1986), proposed 3 hypotheses that are associated with opportunist managers: Bonus Plan Hypothesis, Debt Covenant Hypothesis, Political Cost Hypothesis

According to Jensen and Meckling (1976), agency theory is a contract under one or more involving agents to carry out some services for them by delegating decision-making authority to the agents. Both managers and agents are assumed to be economically rational and are motivated solely by personal interest. Ricardian hypothesis was put forward by Lee and Hsieh (1985). Classical Ricardian states that managers have the sole purpose to maximize the corporate value by minimizing tax costs and being respectful of tax law constraints and investment production opportunities (Lee and Hsieh, 1985).

\section{Hypothesis Development}

According to Riyanto (2010: 343), company size is the size of a company from its total asset value. The use of the average method results in lower profits and lower taxes than the FIFO method (Simeon and John, 2018). While FIFO method is suitable for small companies to generate greater profits (Stice, 2011: 600). Several previous researches conducted by Cushing and LeClere (1992) and Taqwa, et al (2003) prove that company size affects the choice of inventory accounting methods, so the research hypothesis is: $\mathrm{H} \_1$ : Company size affects the choice of inventory accounting method.

According to Taqwa, et al. (2003), inventory variability is a variation of a company's inventory value. The use of the average method results in lower ending inventory. While the use of the FIFO method results higher ending inventory so that the profit will also be high. Research conducted by Lee and Hsieh (1985), Cushing and LeClere (1992), and Taqwa, et al. (2003) prove that inventory variability has a significant effect on the choice of inventory accounting methods, so the research hypothesis is: H_2: Inventory variability affects the choice of inventory accounting method.

According to Gibson (1997), if the cost of goods sold is determined by a different method, it will have a substantial effect on the income statement. The use of the FIFO method will result in low cost of goods sold and high gross profit (Stice, 2011: 600). Several previous researches conducted by Cushing and LeClere (1992) and Hanum (2016) prove that variability in cost of goods sold affects the choice of inventory accounting methods, so the research hypothesis is: H_3: Variability of cost of goods sold affects the choice of inventory accounting method. 
According to Kasmir (2008: 34), gross profit margin is an analysis used to determine the amount of gross profit from a period to the next period. The use of the average method results in lower profits and lower taxes than the FIFO method (Simeon and John, 2018). Research conducted by Mahardika, et al. (2017) explains that gross profit margin affects the choice of inventory accounting methods, so the research hypothesis is: H_4: Gross profit margin affects the choice of inventory accounting method.

According to Harahap (2009), current ratio is a standard used to determine company's ability to meet its short-term obligations. Research conducted by Cushing and LeClere (1992) prove that current ratio affects the choice of inventory accounting methods, so the research hypothesis is: H_5: Current ratio affects the choice of inventory accounting method.

According to Fakhrudin (2008: 19), leverage is the amount of debt used to finance/buy company assets. The results of research conducted by Cushing and LeClere (1992), prove that leverage affects the choice of inventory accounting methods, so the research hypothesis is: H_6: Leverage affects the choice of inventory accounting method.

According to Pasaribu, Topowijono, and Sri (2016), managerial ownership is the shareholder by the company management who actively plays a role in decision making. Research conducted by Hanum (2016) confirms that managerial ownership has a significant effect on the choice of inventory accounting methods, so the research hypothesis is: H_7: Managerial ownership affects the choice of inventory accounting method.

\section{RESEARCH METHODOLOGY}

This research is a quantitative research. The population in this research was manufacturing companies listed in the Indonesia Stock Exchange (IDX) for the period of 2015-2018. The sample used in this research was obtained using a purposive sampling method.

The dependent variable used in this research was the choice of inventory accounting methods. The choice of inventory accounting methods between the FIFO method and the average method as the dependent variable was based on PSAK 14 (2008). The dependent variable was qualitative and a dummy variable. Therefore, measurements were performed using a nominal scale. The indicator for this variable was 0 for the FIFO method and 1 for the average method.

Independent variables: Company size was determined by the total assets owned by the company. This variable was measured from the average total assets i.e. the sum of the total assets of each sample company from 2015 to 2018 divided by the number of observation period, which was 4 . After obtaining the average of total asset, then it was measured using natural logarithms with UP = Ln Total Assets.

Inventory variability was measured based on the coefficient of variation in ending inventory that is the standard deviation/mean for 4 years, 2015-2018.

$$
\mathrm{VP}=\frac{\text { Standard deviation of ending inventory }}{\text { Mean of Ending Inventory }}
$$

Variability of cost of goods sold was calculated based on the coefficient of cost of goods sold obtained from standard deviation of the measurement scale in the form of ratio of cost of goods sold divided by the mean cost of goods sold during the observation period.

$$
\mathrm{VH}=\frac{\text { Standard deviation of Cost of Goods Sold }}{\text { Mean of Cost of Goods Sold }}
$$

Gross profit margin illustrates the gross profit gained from the net sales. Gross profit margin can be measured by:

$$
\mathrm{LB}=\frac{\text { Total Gross Profit }}{\text { Average Sales }}
$$


Current ratio shows how far the demands of short-term creditors can be met by the assets expected to be converted into cash within the accounting over obligations due within the same period. The current ratio variable was measured by dividing current asset with the current liabilities. The value of each observation year was summed up and divided by the number of observation years that was 4 .

$$
\mathrm{RL}=\frac{\text { Current Assets }}{\text { Current Liabilities }}
$$

Leverage was measured by dividing long-term debt with equity. The value of each observation year was summed up and divided by the number of observation years that was 4.

$$
\mathrm{LV}=\frac{\text { Total Long-term Debt }}{\text { Total Equity }}
$$

Managerial ownership was measured by a dummy variable that was 1 (one) if the manager had shares in the company or 0 (zero) if the manager had no share in the company.

Data analysis technique used in this research was logistic regression. The model used in this research was as follows:

Description:

$$
\operatorname{Ln} \frac{P}{1-P}=\alpha+\beta_{1} U P+\beta_{2} V P+\beta_{3} V H+\beta_{4} L B+\beta_{5} R L+\beta_{6} L V+\beta_{7} K M+e
$$

$\mathrm{P}=$ Probability of a company to choose the inventory accounting method was 0 if the company chose the FIFO method and 1 if it choses the average method.

a : Constant

$\beta_{1}$ : Regression Coefficient of Company Size

$\beta_{2}$ : Regression Coefficient of Inventory Variability

$\beta_{3}$ : Regression Coefficient of Cost of Goods Sold Variability

$\beta_{4}$ : Regression Coefficient of Gross Profit Margin

$\beta_{5}$ : Regression Coefficient of Current Ratio

$\beta_{6}$ : Regression Coefficient of Leverage

$\beta_{7}$ : Regression Coefficient of Managerial Ownership

UP: Company Size

VP: Inventory Variability

VH: Cost of Goods Sold Variability

LB: Gross Profit Margin

RL: Current Ratio

LV: Leverage

KM: Managerial Ownership

e: error 


\section{FINDINGS AND DISCUSSION}

\section{Findings}

The research population were 162 companies listed in the Indonesia Stock Exchange (IDX) from 2015-2018. In this population, the researchers obtained 73 manufacturing companies that met the sampling criteria, consisting of:

Table 1. Criteria for selecting samples of manufacturing companies

\begin{tabular}{clc}
\hline No & \multicolumn{1}{c}{ Description } & Total \\
\hline 1 & $\begin{array}{l}\text { Manufacturing company listed in the Indonesia Stock Exchange } \\
\text { during 2015-2018 }\end{array}$ & 162 \\
\hline 2 & $\begin{array}{l}\text { The company did not issue financial statements consecutively } \\
\text { during the observation period }\end{array}$ & $(7)$ \\
\hline 3 & $\begin{array}{l}\text { The company financial statements were not stated in rupiah during } \\
\text { the observation period }\end{array}$ & $(36)$ \\
\hline 4 & The company suffered losses during the observation period & $(6)$ \\
\hline 5 & $\begin{array}{l}\text { The company did not use FIFO method and average method for } \\
\text { inventory accounting methods }\end{array}$ & $(0)$ \\
\hline 6 & $\begin{array}{l}\text { The company used more than one inventory accounting methods } \\
\text { during the observation period }\end{array}$ & $(30)$ \\
\hline 7 & $\begin{array}{l}\text { The company did not use inventory accounting method consistently } \\
\text { during the observation period }\end{array}$ & $(0)$ \\
\hline 8 & The financial statement data was incomplete & $(10)$ \\
\hline & \multicolumn{1}{l}{ Total Sample } & 73 \\
\hline
\end{tabular}

Table 2. Group of company samples by inventory method

\begin{tabular}{cccc}
\hline No & Inventory Method & Total & Percentage \\
\hline 1 & FIFO & 7 & $11,11 \%$ \\
\hline 2 & Average & 66 & $88,89 \%$ \\
\hline & Total & 73 & $100 \%$ \\
\hline
\end{tabular}

\section{Descriptive Statistics}

The following is the results of descriptive analysis:

Table 3. Descriptive Statistics Test Results

\begin{tabular}{ccccc}
\hline & Mini & Max & Mean & Std. Deviation \\
\hline UP & 144.287 .445 .463 & 45.651 .138 .838 .500 & 5.334 .240 .130 .050 & 8.718 .462 .461 .367 \\
\hline VP & 0,02 & 1,17 & 0,2039 & 0,15313 \\
\hline VH & 0,02 & 0,95 & 0,1675 & 0,15180 \\
\hline LB & 0,04 & 2,84 & 0,9995 & 0,63743 \\
\hline RL & 0,59 & 7,47 & 2,3829 & 1,62864 \\
\hline LV & 0,01 & 2,10 & 0,3246 & 0,41465 \\
\hline KM & 0 & 1 & 0,5342 & 0,50228 \\
\hline P & 0 & 1 & 0,9041 & 0,29648 \\
\hline Source: Data Processing Results of IBM SPSS Statistics 21,2019 & &
\end{tabular}

\section{Logistic Regression Test}

-2 Log Likelihood Test

The overall test results of the -2LogL model on block number 0 in this research indicate that $-2 \log \mathrm{L}$ wass 46.130 . In block number 1 , it shows that the value of $-2 \mathrm{LogL}$ after added by seven variables, the final value of the -2LogL test dropped to 27.866 . The decline in the value of $-2 \log \mathrm{L}$ shows that the addition of seven independent variables to 
the model can improve the fit model with the data and show a better regression model. The statistical value of $-2 \operatorname{LogL}$ can be seen in the following table:

Table 4. Test Results of -2 Log Likelihood Values

\begin{tabular}{cc}
\hline Iteration & -2 Log Likelihood \\
\hline Block Number & \\
\hline 0 & 46,130 \\
\hline 1 & 27,866 \\
\hline \multicolumn{2}{l}{ Source: Data Processing Results of IBM SPSS Statistics 21, 2019 }
\end{tabular}

\section{Determination Coefficient Test (Nagelkerke's $R$ Square)}

Based on the results of SPSS output, it shows that the value of Cox \& Snell $R$ Square was 0.221 and Nagelkerke's R Square value was 0.473. It means that the variability of the dependent variable that can be explained by the variability of the independent variable by $47.3 \%$. This result means that there was $52.7 \%$ dependent variable that can be explained by other independent variables outside the variables of this research. This test can be seen in the table as follows:

Table 5. Determination Coefficient Test Results

\begin{tabular}{cccc}
\hline Step & -2 Log likelihood & Cox \& Snell R Square & Nagelkerke R Square \\
\hline 1 & 27,866 & 0,221 & 0,473 \\
\hline \multicolumn{2}{l}{ Source: Data Processing Results of IBM SPSS Statistics 21, 2019 }
\end{tabular}

\section{Hosmer and Lemeshow Test}

Based on the results of the SPSS output, it shows that the Chi-square value of 5.230 with a significance value is much greater at 0.733 . This test can be seen in the table as follows:

Table 6. Hosmer and Lemeshow Test Results

\begin{tabular}{cccc}
\hline Step & Chi-square & Df & Sig. \\
\hline 1 & 5,230 & 8 & 0,733 \\
\hline \multicolumn{4}{l}{ Source: } \\
Data Processing Results of IBM
\end{tabular}

\section{Hypothesis Test}

The following table presents the hypothesis test results in this research:

$\operatorname{Ln} \frac{\mathrm{P}}{1-\mathrm{P}}=-46,139+1,774 \mathrm{UP}-10,049 \mathrm{VP}+4,947 \mathrm{VH}-1,279 \mathrm{LB}+0,460 \mathrm{RL}+2,525 \mathrm{LV}+$ $1,562 \mathrm{KM}$

Table 7. Hypothesis Test Results

\begin{tabular}{ccccc}
\hline Variable & B & S.E & Wald & Sig. \\
\hline UP & 1,774 & 0,866 & 4,199 & 0,040 \\
\hline VP & $-10,049$ & 4,312 & 5,430 & 0,020 \\
\hline VH & 4,947 & 5,287 & 0,876 & 0,349 \\
\hline LB & $-1,279$ & 0,903 & 2,005 & 0,157 \\
\hline RL & 0,460 & 0,385 & 1,431 & 0,232 \\
\hline LV & 2,525 & 3,198 & 0,623 & 0,430 \\
\hline KM & 1,562 & 1,376 & 1,289 & 0,256 \\
\hline Constant & $-46,139$ & 23,748 & 3,775 & 0,052 \\
\hline Source: Data Processing Results of IBM SPSS Statistics 21, 2019 &
\end{tabular}

\section{Discussion}

The test result of company size variable indicates a significance value of 0.040 or $\mathrm{p}$ $<0.05$. It can be concluded that company size has an effect on the choice of inventory accounting methods. This research results support the research conducted by Cushing and LeClere (1992), Taqwa, et al. (2003), and Mahardika, et al. (2017) stating that company size affects the choice of inventory accounting methods. However, the research 
result contradicts the research conducted by Lee and Hsieh (1985), and Hanum (2016) stated that company size has no effect on the choice of inventory accounting methods.

The test result of inventory variability variable indicates a significance value of 0.020 or $\mathrm{p}<0.05$. It can be concluded that the variability affects the choice of inventory accounting methods. This research results support research conducted by Lee and Hsieh (1985), Cushing and LeClere (1992), and Taqwa, et al. (2003) stating that inventory variability affects the choice of inventory accounting methods. However, it contradicts the research conducted by Hanum (2016) which provided evidence that inventory variability had no effect on the choice of inventory accounting methods. The test result of cost of goods sold variability variable indicates a significance value of 0.349 or $p>0.05$. It can be said that the variability of cost of goods sold has no effect on the choice of inventory accounting method. This research results support the research conducted by Mahardika et al. (2017) stating that the variability of cost of goods sold has no effect on the choice of inventory accounting methods. However, it contradicts the research conducted by Cushing and LeClere (1992), and Hanum (2016) which provided evidence that variability in cost of goods sold affected the choice of inventory accounting methods.

The test result of current ratio variable indicates a significance value of 0.232 or $p>$ 0.05. It can be said that the current ratio has no effect on the choice of inventory accounting method. This research results support research conducted by Taqwa, et al. (2003), and Hanum (2016) stating that the current ratio has no effect on the choice of inventory accounting methods. However, it contradicts the research conducted by Cushing and LeClere (1992) stated that the current ratio affected the choice of inventory accounting methods.

For the leverage variable test result, it indicates the significance value of 0.430 or $p>0.05$. It can be said that leverage variable has no effect on the choice of inventory accounting methods. This research results support research conducted by Taqwa, et al. (2003) showing that leverage has no effect on the choice of inventory accounting methods. However, it contradicts the research conducted by Cushing and LeClere (1992) and Hanum (2016) which provided evidence that leverage affected the choice of inventory accounting methods. Leverage test result indicates the significance value of 0.256 or $\mathrm{p}>0.05$. It can be said that managerial ownership has no effect on the choice of inventory accounting methods. This research results support research conducted by Taqwa, et al. (2003) providing evidence that managerial ownership has no effect on the choice of inventory accounting methods.

\section{CONCLUSIONS AND SUGGESTIONS}

Based on the overall results of this research, it can be concluded that company size and inventory variability affect the choice of inventory accounting methods. The variability of cost of goods sold, gross profit margin, current ratio, leverage, and managerial ownership have no effect on the choice of inventory accounting methods. Therefore, it is suggested to the future research to consider other factors for more complex test results, use other methods, and extend the period of observation that can possibly provide a more comprehensive variant.

\section{REFERENCES}

Cushing B.E dan M.J Lee Clere. 1992. "Evidence in the Determinants of Inventory Accounting Policy Choice. The Accounting Review". pp 355-366

Fakhrudin, Hendy M. 2008. Istilah Pasar Modal A-Z. Jakarta:Elex Media Komputindo

Gibson, James L. 1997. Organisasi dan Manajemen. Jakarta:Salemba Empat

Hanum. 2016. Analisis Faktor-Faktor yang Berpengaruh Terhadap Pemilihan Metode Akuntansi Persediaan. Universitas Muhammadiyah Yogyakarta 
Harahap, Rosana K dan Jiwana, Dwi Mradipta. 2009. Analisis Faktor-Faktor yang Berpengaruh Terhadap Pemilihan Metode Akuntansi Persediaan Pada Perusahaan Manufaktur di Bursa Efek Jakarta. Media Riset Akuntansi, Auditing dan Informasi, Vol 9, No. 3, pp. 74-95

Ikatan Akuntan Indonesia. 2008. Standar Akuntansi Keuangan. Jakarta:Salemba Empat

Jensen, M. and Meckling, W. 1976. "Theory of the Firm: Managerial Behavior Agency Cost, and Ownership Structure", Journal of Finance Economics 3. Pp. 305-360

Kasmir. 2008. Analisis Laporan keuangan. Rajawali Pers. Jakarta

Lee and D. Hsieh. 1985. "Choice of Inventory Accounting Method: Competitive Analysis of Alternative Hypothesus", Journal of Accounting Research 23, Autumn. pp 485486

Mahardika, Tutuk. 2017. Analisis Pengaruh Ukuran Perusahaan, Variabilitas Persediaan, Variabilitas Harga Pokok Penjualan, Perputaran Persediaan dan Margin Laba Kotor Terhadap Pemilihan Metode Akuntansi Persediaan Fakultas Ekonomi Universitas Islam Malang. Malang

Pasaribu, M.Y., Topowijono., dan Sulasmiyati, Sri. 2016. Pengaruh Struktur Modal, Struktur Kepemilikan dan Profitabilitas Terhadap Nilai Perusahaan Pada Perusahaan Sektor Industru Dasar dan Kimia yang Terdaftar di BEI Tahun 20112014. Jurnal Administrasi dan Bisnis (JAB), Vol 35, No. 1, Juni, pp 154-164

Pemerintah Republik Indonesia. 1994. Undang-undang Republik Indonesia Nomor 10 Tahun 1994 Tentang Pajak Penghasilan. Jakarta

Riyanto, Bambang. 2010. Dasar-Dasar Pembelanjaan Perusahaan. Edisi pertama. Yogyakarta:Yayasan Penerbit Gajah Mada.

Scott, W. R. 2000. Financial Accounting Theory. Second Edition. Scarborough, Ontario: Prentice Hall Canada Inc.

Simeon, Edori Daniel dan Ohaka, John. 2018. Implication of Choice of Inventory Valuation Methods on Profit, Tax, and Closing Inventory. Account and Financial Management Journal. Vol 3, Issue 7. Nigeria

Stice, J.F., Stice. E.K., \& Skousen. F. 2011. Intermediate Accounting. Edisi Keenam belas. Australia: South-Western.

Taqwa, Salma., Sugiyanto, FX. Dan Daljono (2003). Faktor-faktor yang Mempengaruhi Pemilihan Metode Akuntansi Persediaan Pada Perusahaan Manufaktur di BEJ. Jurnal Riset Akuntansi Indonesia. Vol 2. pp 100-118

Watts, R. L., Zimmerman. 1986. Positive Accounting Theory. Prentice-Hall International. Englewood Cliff. New Jersey 